\title{
New approaches to osteoporosis in primary care
}

\section{Noi abordări ale osteoporozei în asistența medicală primară}

\author{
Mihaela Daniela BALTĂ ${ }^{1}$, Mihaela Adela IANCU1 ${ }^{1}$, Dumitru MATEI ${ }^{1,2}$ \\ ${ }^{1}$ Universitatea de Medicină şi Farmacie „Carol Davila“, Bucureşti, România \\ 2Institutul Naţional pentru Sănătatea Mamei şi Copilului „Alessandrescu-Rusescu“, \\ Bucureşti, România
}

\section{ABSTRACT}

Osteoporosis is a disease that affects an increasing number of people, given the tendency of aging populations. Fragile bone and increases risk of bones breaking, their consequences, impairment of quality of life have prompted health policies to provide a greater insight into this condition. It is important to identify the risk factors and start the preventive and curative treatment as early as possible. Current guidelines recommend using the FRAX score to determine the risk of major fracture over the next 10 years, followed by DXA determination. The current guidelines highlight the importance of non-medication measures, calcium and vitamin D intake. Among the therapeutic agents used in the treatment of osteoporosis, the first line are bisphosphonates po or, in case of intolerance, bisphosphonates iv or antibodies anti RANKL (denosumab). Selective estrogen receptor modulators and hormone replacement therapy are not routinely indicated, and recombinant PTH is expensive and is intended for severe and resistant forms. The adherence to treatment is poor, so we need measures to increase prevention, screening and early treatment of osteoporosis, as well as measures to educate the population.
\end{abstract}

Keywords: osteoporosis, FRAX, DMO, bisphosphonates

\section{REZUMAT}

Osteoporoza este o boală care afectează un număr tot mai mare de persoane, având în vedere tendința de îmbătrânire a populației. Fracturile de fragilitate, consecințele lor, afectarea calității vieții au determinat politicile de sănătate să acorde o însemnătate sporită acestei afecțiuni. Este important să identificăm factorii de risc şi să începem tratamentul preventiv şi curativ cât mai precoce. Actualele ghiduri recomandă utilizarea scorului FRAX pentru a stabili riscul de fractură majoră în următorii 10 ani, urmat de determinarea DMO prin DXA. Ghidurile actuale subliniază importanța tratamentului nemedicamentos, măsuri igienodietetice, promovarea exercițiului fizic, renunțare la fumat, aport de calciu şi vitamina D. Dintre agenții terapeutici folosiți în tratarea osteoporozei, ca primă linie sunt menționați bifosfonații po sau, în caz de intoleranță, bifosfonații im sau anticorpi anti RANKL (denosumab). Modulatori selectivi ai receptorilor de estrogen şi terapia de substituție hormnonală nu sunt indicate de rutină, iar PTH recombinat este scump, fiind destinat formelor severe rezistente la alte terapii. Deoarece aderența şi persistența la tratament sunt slabe, sunt necesare măsuri de creştere a prevenției, de depistare şi tratare precoce a afecțiunii, precum şi măsuri de educare a populației.

Cuvinte cheie: osteoporoza, FRAX, DMO, bifosfonați 
Osteoporoza a fost definită încă din anul 1994 de OMS ca o boală sistemică scheletală caracterizată prin pierdere de masă osoasă, alterarea arhitecturii osoase, având drept consecinţe creșterea fragilităţii osoase și a riscului de fractură. Se știe că acumularea de capital osos are loc de la naștere și până în jurul vârstei de 25-30 de ani, când se consideră că atinge un maximum, după care se menţine într-un oarecare platou până în jurul vârstei de 45-50 de ani, în condiţiile unei diete corecte, ale expunerii normale la radiaţia solară (10 minute de 2 ori pe zi sunt suficiente la latitudinea ţării noastre) și ale evitării unui stil de viaţă sedentar. După această vârstă, pierderea de capital osos se consideră a fi fiziologică în proporţie de $0,5-1 \%$ pe an, respectiv de 1-2\% pe an în cazul femeilor aflate la menopauză.

Osteoporoza a devenit în ultimii ani o problemă foarte importantă pentru politicile de sănătate ale ţărilor dezvoltate în special, lucru explicat de creșterea impresionantă a populaţiei cu osteoporoză și risc crescut de fracturi; deoarece în ultimele decenii s-au înregistrat îmbătrânirea populaţiei și creșterea speranţei de viaţă, tot mai multe persoane vor avea neșansa de a suferi o fractură de fragilitate în decursul vieţii. De asemenea, instalarea menopauzei la vârste din ce în ce mai tinere (40-50 de ani) și faptul că mai mult de o treime din viaţa unei femei se desfășoară după menopauză au determinat creșterea marcată a prevalenţei osteoporozei și fracturilor în rândul acestei populaţii. în prezent, se consideră că $1 / 3$ dintre femei, respectiv $1 / 5$ dintre bărbaţi vor suferi o fractură de fragilitate în de- cursul vieţii. De altfel, previziunile pentru anul 2050 estimează o creștere a incidenţei fracturilor osteoporotice de $240 \%$ în cazul femeilor și de $310 \%$ în cazul bărbaţilor.

Osteoporoza reprezintă o afecţiune ce presupune costuri ridicate din partea societăţii dacă sunt considerate zilele de spitalizare, de incapacitate de muncă, necesităţile de îngrijire la domiciliu în anumite situaţii, disfuncţionalităţile și invalidităţile ce pot apărea în urma fracturilor; uneori, pot să apară complicaţii importante, mergând chiar până la deces (se citează până la $20 \%$ decese în primul an după o fractură de șold). De asemenea, afectează într-o măsură ridicată calitatea vieţii atât prin consecinţele funcţionale, cât și prin aspectul fizic (cifoze, scolioze, scurtarea membrelor etc.) ce determină în timp manifestări de tip depresiv.

Se descriu o multitudine de factorii etiologici care sunt consideraţi că ar putea favoriza apariţia fracturilor de fragilitate (1). Unii dintre acești factori au o importanţă aparte în estimarea riscului de fractură și de aceea au fost incluși în algoritmul FRAX de evaluare a riscului de fractură, pe lângă aceștia descriindu-se însă o multitudine de alţi factori care pot contribui la favorizarea osteoporozei și fracturilor (Tabelul 1) (2).

\section{Diagnosticul clinic}

Osteoporoza este o afecţiune silenţioasă care evoluează mult timp asimptomatic, astfel încât pacienţii ajung la medic în fazele avansate, când apar modificări ale scheletului sau fracturi. Astfel, pacienţii pot acuza dureri toraco-lombare ce

TABELUL 1. Factori de risc pentru osteoporoză şi fracturi de fragilitate

\begin{tabular}{|c|c|}
\hline Factori de risc incluși în algoritmul FRAX & Alți factori de risc \\
\hline $\begin{array}{l}\text { - Vârsta } \\
\text { - Sex (femei) } \\
\text { - Rasa (caucaziană, asia ci) } \\
\text { - IMC mic < } 19 \mathrm{~kg} / \mathrm{mp} \\
\text { (risc pentru fractura de șold) } \\
\text { - antecedente recente de fractură } \\
\text { (crește de } 2 \text { ori risc de fractură) } \\
\text { - AHC de fractură } \\
\text { - Menopauză/hipogonadism (<45 de ani) } \\
\text { - Fumat } \\
\text { - Alcool în exces } \geq 3 \text { u/zi } \\
\text { - Cor coterapie pe termen lung } \geq 3 \text { luni } \\
\text { - Poliartrită reumatoidă } \\
\text { - OP secundară (malnutriţie, } \\
\text { malabsorbţie, boli hepa ce, boli } \\
\text { renale, diabet zaharat p I, osteogenesis } \\
\text { imperfecta, hiper roidism netratat) }\end{array}$ & $\begin{array}{l}\text { - Diabet zaharat p II } \\
\text { - Căderi } \\
\text { - Sedentarism } \\
\text { - Imobilizare prelungită (> } 6 \text { luni) } \\
\text { - Boli inflamatorii (spondilită, LES, boli intes nale inflamatorii) } \\
\text { - Boli endocrine (tratament cu hormoni roidieni, hiperpara roidism, } \\
\text { hipercor cism) } \\
\text { - Boli hematologice } \\
\text { - Boli musculare (miozite, miopa i, distrofii) } \\
\text { - HIV } \\
\text { - Astm, BPOC } \\
\text { - Boli neurologice (Parkinson, scleroză mul plă, epilepsie, demenţă) } \\
\text { - Aport scăzut de calciu în alimentaţie }<400 \text { mg/zi } \\
\text { - Aport scăzut de vitamina D și expunere redusă la soare } \\
\text { - Tratamente hormonale în cancere hormonodependente, an coagulante, } \\
\text { an convulsivante, inhibitori de pompă de protoni, an diabe ce } \\
\text { - Stres oxida v } \\
\text { - Microbiota intes nală } \\
\text { - Epigene c }\end{array}$ \\
\hline
\end{tabular}


apar în special după ortostatism prelungit; uneori durerile pot fi resimţite ca radiculită atunci când are loc compresia rădăcinilor nervoase, ca urmare a prăbușirii vertebrelor. De asemenea, printre primele semne care apar în cazul osteoporozei vertebrale se numără scăderea în înălţime, care este considerată ca semn clinic atunci când depășește $4 \mathrm{~cm}$. O cifoză recent apărută poate considerată semn de fractură vertebrală; de asemenea, când cifoza este accentuată, scade și distanţa iliocostală, apar și scolioza și consecutiv tulburări de statică, asimetrii ale umerilor și bazinului. Sediile cele mai frecvente ale fracturilor de fragilitate sunt: corpul vertebral, extremitatea distală a radiusului (fracturi Colles sau Smith la nivelul pumnului prin sprijinire pe mână), extremitatea proximală a femurului (col femural) (2).

În unele cazuri, când modificările la nivelul coloanei vertebrale sunt importante, apare disfuncţie ventilatorie de tip restrictiv cu dificultate la respiraţie, dispnee, scăderea capacităţii de efort. Depresia este adesea fenomen de însoţire, apărând ca urmare a aspectului fizic neplăcut, dar și a limitării eforturilor, scăderea abilităţilor ca urmare a sechelelor fracturilor. După fracturile de șold, mai ales după imobilizările prelungite, există riscul apariţiei tromboemboliilor sau a leziunilor de decubit.

\section{Explorări paraclinice}

1. Algoritmul FRAX este un instrument de calcul care ne ajută să determinăm riscul absolut de fracturare pentru o persoană, luând în considerare anumiţi factori de risc: sex, vârstă, greutate, înălţime, existenţa unei fracturi antecedente sau în istoricul familiei, în special la mamă, fumat, tratamente cu corticosteroizi, poliartrită reumatoidă, consumul excesiv de alcool și evaluarea densitometrică. Algoritmul FRAX estimează probabilitatea de a suferi o fractură de șold sau o fractură osteoporotică majoră (coloană vertebrală, antebraţ, șold sau umăr) în următorii 10 ani. Acest algoritm permite calcularea riscului în cazul persoanelor cu vârsta cuprinsă între 40 și 90 de ani. Ghidurile actuale recomandă evaluarea riscului de fractură la toate femeile aflate la menopauză și la bărbaţii cu vârsta de peste 50 de ani, care au factori de risc pentru osteoporoză $(2,4)$. Scorul FRAX este adaptat fiecărei ţări, de aceea, la accesare, se va selecta ţara în care se aplică și se recomandă să fie efectuat de către medic înainte de alte investigaţii pentru osteoporoză (Fig. 1). Dacă riscul de fractură este mare (Fig. 2) se recomandă determinarea DMO, urmată de iniţierea terapiei $(4,1)$.

2. Determinarea densităţii minerale osoase DMO $\left(\mathrm{g} / \mathrm{cm}^{2}\right)$ se face prin dublă absorbţiometrie cu raze $X$ (DXA) la nivelul coloanei vertebra-

\section{Calculator de risc}

Va rugam sa raspundeti la urmatoarele intrebari pentru a calcula probabilitatea de fractura la 10 ani folosind DMO.

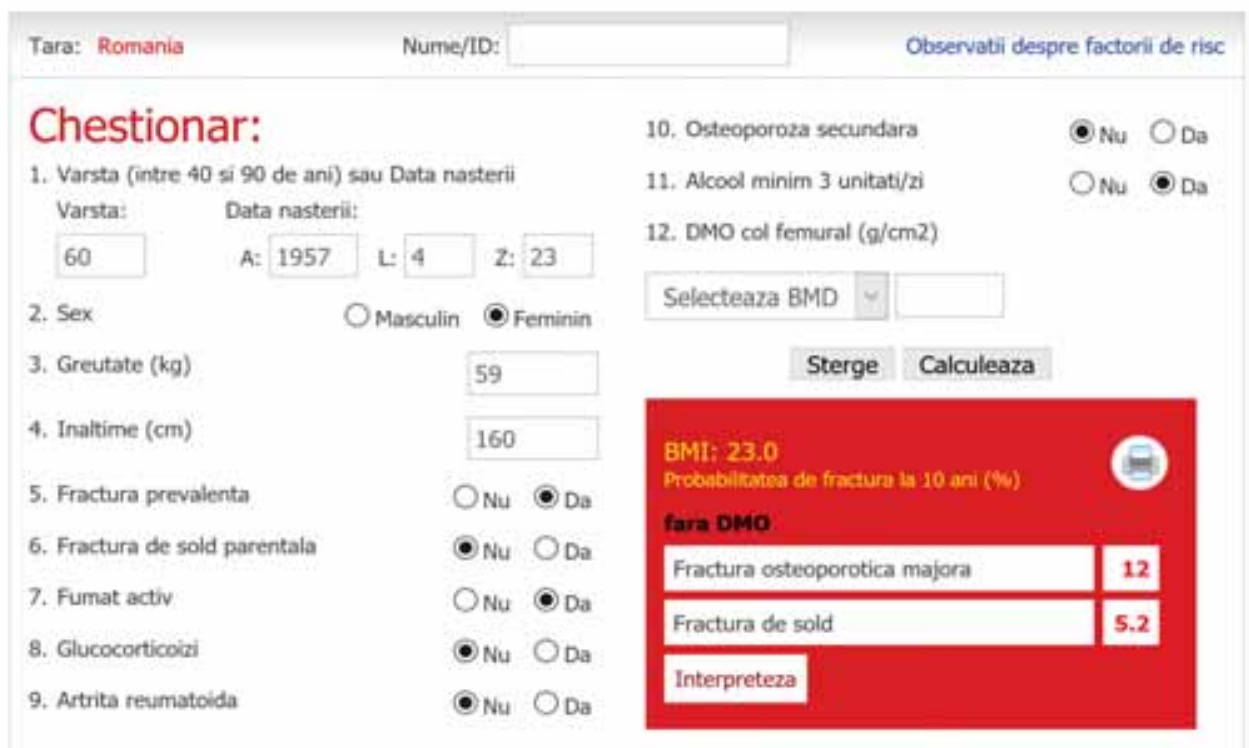

FIGURA 1. Algoritmul FRAX 


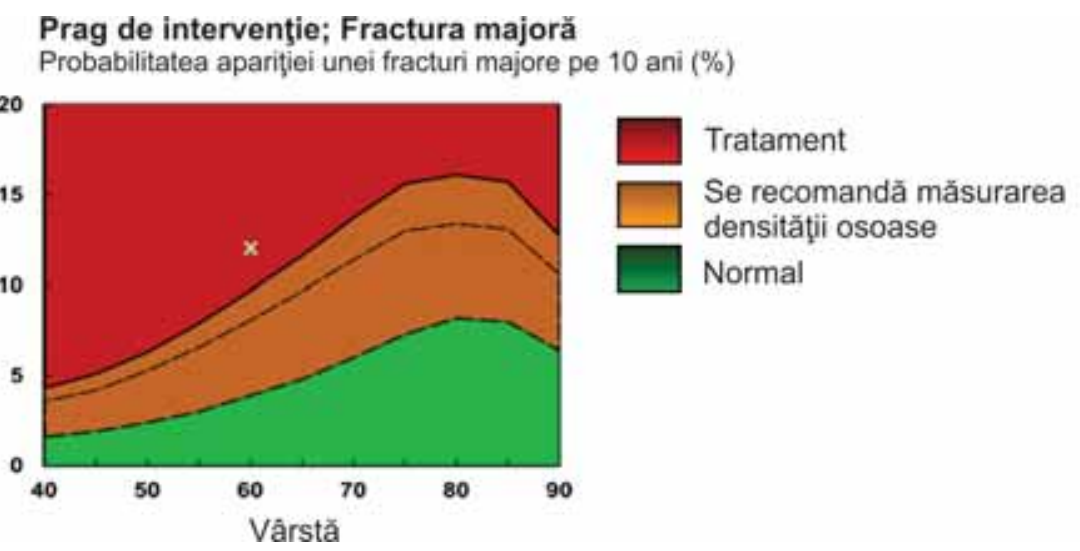

FIGURA 2. Interpretarea rezultatului algoritmului FRAX

le, șoldului, antebraţului (radius), ultima situaţie fiind considerată atunci când la celelalte două niveluri rezultatele nu sunt elocvente sau nu se pot efectua determinări (1). La nivelul coloanei vertebrale, de multe ori se obţin rezultate false, în special în cazul persoanelor vârstnice care au modificări artrozice la nivelul coloanei și cifoscolioze importante; acest segment însă este considerat de ghiduri ca util în monitorizarea efectului tratamentului. Determinările DXA la nivelul femurului (col femural) sunt însă frecvent sediile utile în determinarea gradului osteoporozei înainte de debutul terapiei. Dacă se obţin valori diferite la nivelul celor trei segmente, se consideră valoarea cea mai severă ca nivel de referinţă. Dacă DMO $<-2,5$ deviaţii standard, raportat la media persoanelor sănătoase de 25 ani (când capitalul osos este maxim), ne aflăm în faţa unei osteoporoze, fiind necesar tratament cu agenţi specifici. Dacă DMO are valori cuprinse între -1 și $-2,5$, se consideră că pacientul prezintă osteopenie și necesită monitorizare și terapie igienodietetică, calciu și vitamina $\mathrm{D}$. Aceste valori sunt valabile atât pentru femei, cât și pentru bărbaţi. În interpretarea DXA avem în vedere Scorul T, care reprezintă diferenţa DMO pacient și valoarea medie în populaţia tânără exprimată în deviaţii standard, scor care are importanţă în evaluarea osteoporozei la vârstnici și femei la menopauză. Scorul Z, care reprezintă diferenţa între DMO pacient și valoarea medie a populaţiei de aceeași vârstă și sex, este util în special la bărbaţi și femei premenopauză. Literatura de specialitate a acordat o importanţă deosebită determinării DMO, făcând o analogie între valoarea determinării TA pentru diagnosticul HTA cu valoarea pe care o reprezintă determinarea DMO pentru determinarea riscului în fractura de șold. DXA reprezintă și modalitatea de monitorizare și control al eficienţei terapiei, ajutând la stabilirea duratei tratamentului.
3. Ultrasonometria osoasă efectuată la nivelul calcaneului, tibiei, patelei sau radiusului a fost utilizată ca metodă screening pentru osteoporoză. În prezent, din cauza sensibilităţii reduse și slabei corelaţii cu osteoporoza (60\%), nu se mai efectuează de rutină; în plus, rezultatele false obţinute la persoanele cu tulburări circulatorii venoase și limfatice sau cu diferite alte probleme plantare au limitat mult utilitatea acestei metode.

4. Radiografia osoasă evidenţiază modificări osteoporotice în stadii avansate ale bolii, atunci când s-a pierdut peste $30-40 \%$ din masa osoasă. Pot să apară scăderea înălţimii vertebrelor, semnificativă fiind scăderea cu peste $20 \%$ din total sau diminuarea cu peste $4 \mathrm{~mm}$ a înălţimii unei vertebre; zona de elecţie în care apar primele modificări este zona toracală medie și zona de tranziţie T12 - L1, celelalte zone ale coloanei fiind afectate în stadii mai tardive. La nivelul colului femural apare evident aspectul trabecular, la acest nivel apărând în timp fracturile de fragilitate.

5. TC cantitativă realizează măsurarea volumetrică a DMO, dar, fiind scumpă, nu este utilizată în practica medicală de rutină.

6. Alte investigaţii paraclinice necesare în diagnosticul osteoporozei includ: analize uzuale și probe inflamatorii (hemoleucograma, VSH, PCR), dozarea calcemiei și fosfatemiei, dozări hormonale pentru excluderea unor cauze de osteoporoză secundară (PTA, TSH, FT4, estradiol, testosteron, cortizol), dozarea serică a 25 hidroxivitaminei D. De asemenea, dozarea markerilor de osteoformare (fosfataza alcalină - izoenzima osoasă, osteocalcina, propeptid carboxiterminal al colagenului I) sau a markerilor de osteoresorbţie (aminopeptide, telopeptide crosslinkate ale colagenului I, piridolina și dezoxipiridolina în urină) pot ajuta la diagnosticul precoce al osteoporozei și a tipului de osteoporoză. 
În cazul bărbaţilor cu risc de fractură, se estimează riscul (BMD) în special la nivelul colului femural, iar valorile de referinţă sunt aceleași ca și în cazul femeilor. Investigarea cauzelor de osteoporoză secundară este uzuală în cazul bărbaţilor de peste 50 de ani cu factori de risc prezenţi; sunt consideraţi la risc toţi bărbaţii cu terapie de privare androgenică.

Osteoporoza este întâlnită frecvent în reumatice inflamatorii (poliartrita reumatoidă, LES, spondilita anchilozantă, polimialgia reumatică, vasculite), factorii favorizanţi fiind multipli: inflamaţia însăși, tendinţa de autolimitare a activităţii fizice, hipotrofie musculară, risc de cădere crescut, scăderea IMC în stadii avansate, terapia utilizată, în special corticoterapia sau imunosupresoarele. În ceea ce privește corticoterapia, studiile au demonstrat că, indiferent de calea de administrare (sistemic sau inhalator) și de modul de administrare (continuu sau alternativ), este favorizată apariţia timpurie a osteoporozei la ambele sexe. Ghidurile actuale consideră că o durată a cortcoterapiei de peste 3 luni cu doze $\geq 7,5 \mathrm{mg} / \mathrm{zi}$ determină osteoporoză independent de DMO. Persoanele în vârstă de peste 70 de ani supuse unui tratament cortizonic $(\geq 7,5$ $\mathrm{mg} / \mathrm{zi}$ ) o durată > 3 luni sunt considerate la risc foarte mare și au indicaţie de terapie pentru osteoporoză pe toată perioada corticoterapiei. Recomandarea este de a scurta terapia cortizonică acolo unde se poate, studiile arătând că o proporţie de $50 \%$ dintre pacienţii trataţi cu cortizon timp îndelungat vor face fractură de fragilitate. Riscul cel mai mare de fractură este la debutul terapiei cortizonice, de aceea tratamentul cu vitamina $\mathrm{D}$, calciu și bifosfonaţi se indică chiar de la începerea terapiei cortizonice.

Stabilirea diagnosticului și tipului de osteoporoză, precum și a gradului acesteia este urmată de stabilirea atitudinii terapeutice. Este important să se excludă cauze de osteoporoză secundară, deoarece în aceste situaţii este necesară tratarea bolii de bază înaintea terapiei specifice osteoporozei; de asemenea, tratamentul va fi ales în funcţie de vârstă, sex, comorbidităţi, alte tratamente urmate de către pacient.

\section{Principii terapeutice}

Toate ghidurile de osteoporoză recomandă intensificarea tratamentului nemedicamentos și schimbarea stilului de viaţă $(1,4)$. Astfel, se recomandă renunţarea la fumat, evitarea abuzului de cafea și a consumului de alcool în cantitate mare (recomandat $<2 \mathrm{u} / \mathrm{zi}$ ), ca și o dietă echilibrată, bogată în proteine de calitate superioară, vitamine și minerale (1). Proteinele sunt necesare pentru refacerea matricei organice, alimentele cu proteine de calitate superioară sunt proteinele de provenienţă animală (carne slabă de curcan, pui, vită, porc, albuș de ou, leguminoase). Aportul de proteine trebuie adaptat însă vârstei, comorbidităţilor, fiind mai crescut în cașexie și sindroame de malabsorbţie și scăzut corespunzător în cazul afectării funcţiei renale. Unele studii recente au arătat că soia ar putea ajuta la pierderea mai lentă de masă osoasă, dar sunt necesare studii suplimentare care să confirme acest lucru.

Vitamina $D$ este necesară în condiţii normale în cantitate de 400 ui/zi, necesarul crescând după menopauză și la bărbaţii de peste 50 de ani la 800 ui/zi. Vitamina D este sintetizată la nivelul pielii sub acţiunea radiaţiilor ultraviolete UVB (este suficientă expunerea la soare timp de $10-20$ de minute a unei suprafeţe de $20 \%$ din suprafaţa corpului, fără a folosi creme de protecţie solară în timpul acestor minute). Ca alimente utilizate ca surse naturale de vitamina $D$ menţionăm: macrou, somon, sardine, gălbenuș de ou, tofu. Studiile au demonstrat că vitamina $D$ administrată în doză de 1.000 ui/zi reduce riscul de fractură vertebrală postmenopauză, efect nedemonstrat pentru fracturile nonvertebrale. În cazul afectării funcţiei renale, se preferă administrarea calcitriolului (1,25 dihidroxi-vitamina $D)$ în doză de 0,25 $\mu \mathrm{g} \times 2 /$ zi (2).

Vitamina $\mathrm{K}$ este esenţială pentru formarea osteocalcinei, prin urmare este un aport crescut de alimente verzi (salată, broccoli, spanac, sparanghel, pătrunjel, varză de Bruxelles) ar putea fi benefic în prevenţia osteoporozei. Se știe că vitamina $C$ ajută la sinteza colagenului, inclusiv a celui din oase și articulaţii, de aceea, ea nu trebuie să lipsească din alimentaţie (căpșuni, măceșe, coacăze, citrice, varză, broccoli, conopidă).

Calciul este necesar în mod fiziologic în cantităţi de 700-1.200 mg/zi, fiind preferate sursele din alimentaţie (lactate, spanac, varză, cimbru, broccoli, migdale, cereale integrale). După 50 de ani, dacă aportul de calciu din alimentaţie scade sub $1.200 \mathrm{mg} / \mathrm{zi}$, pot fi necesare suplimente de calciu, dar trebuie avut în vedere că un aport de peste $2.000 \mathrm{mg} / \mathrm{zi}$ poate predispune la litiază renală și unele studii au demonstrat că poate crește riscul de boli cardiovasculare. De asemenea, este necesar un aport suficient de magneziu în alimentaţie (seminţe de dovleac, orez brun, spanac, fasole, seminţe de susan), care va ajuta la absorbţia calciului, iar prezenţa potasiului în dietă se pare că ajută la încetinirea 
declinului densităţii osoase (pepene, prune, banane, migdale, fistic, caise).

Pentru menţinerea masei osoase se recomandă practicarea exerciţiului fizic constant, ideal minimum 30-45 de minute pe zi; se preferă exerciţii izometrice, dar și mers, jogging, schiat, sporturi care pun forţă pe oasele lungi de susţinere. Pacienţilor care deja au osteoporoză li se indică evitarea sporturilor agresive, de echipă, sau cu pericol de cădere. De asemenea, sunt benefice, mai ales în cazul persoanelor vârstnice, exerciţiile de echilibru, pentru a preveni căderile. În cazul fracturilor de tren inferior se indică mobilizare precoce urmată de kinetoterapie, pentru a evita complicaţiile tromboembolice și de decubit ce pot să apară. Se recomandă utilizarea unor saltele ferme, iar în unele cazuri poate fi necesară purtarea unor corsete pentru protejarea coloanei vertebrale când există risc mare de fracturi vertebrale. Pentru evitarea căderilor se recomandă tratarea bolilor care ar putea determina pierderea echilibrului sau a forţei musculare, utilizarea unor mijloace ajutătoare (baston, cadru, cărucioare speciale), amenajarea mediului și locuinţei, folosirea de protectoare pentru șolduri.

Tratamentul medicamentos include două clase de agenţi terapeutici: antiresorbtive (inhibă activitatea osteoclastelor) și medicamente care stimulează anabolismul osos (stimulează activitatea osteoblastelor) (Tabelul 2).

TABELUL 2. Tratament medicamentos în osteoporoză

\begin{tabular}{|l|l|}
\hline Antiresorbtive & Anabolizante osoase \\
\hline Bifosfonaţi & Catena terminală a PTH \\
Ac an RANKL & (teripara de 1-84) \\
Modulatori selec vi ai & Ac an -scleros n \\
receptorilor estrogenici & \\
Calcitonina & \\
Inhibitori de cathepsina & \\
Ranelat de stronţiu & \\
\hline
\end{tabular}

Bifosfonaţii sunt cei mai utilizaţi agenţi terapeutici, toate ghidurile actuale plasându-i în linia I de tratament în toate tipurile de osteoporoză $(1,4)$. Alendronatul este indicat în osteoporoza postmenonopauză $10 \mathrm{mg} / \mathrm{zi}$ sau $70 \mathrm{mg} /$ săptămână, în osteoporoza la bărbaţi $10 \mathrm{mg} / \mathrm{zi}$ sau în prevenirea osteoporozei induse de corticosteroizi $5 \mathrm{mg} / \mathrm{zi}$. Risendronatul are aceleași indicaţii, se folosește în doze de $5 \mathrm{mg} / \mathrm{zi}$ sau 35 $\mathrm{mg} / \mathrm{săptămână.} \mathrm{Spre} \mathrm{deosebire} \mathrm{de} \mathrm{primele}$ două produse, ibandronatul și-a dovedit eficacitatea în osteoporoza vertebrală și nevertebrală, dau nu și în osteoporoza la nivelul șoldului. Se poate utiliza per os în doze de $150 \mathrm{mg} / \mathrm{lună} \mathrm{sau}$ în administrare parenterală $3 \mathrm{mg}$ la fiecare 3 luni. Când bifosfonaţii nu sunt toleraţi per os din cauza reacţiilor adverse gastrointestinale, se indică utilizarea bifosfonaţilor pe cale parenterală. Acidul zolendronic se poate administra în doze de 5 mg iv pe an în osteoporoza postmenopauză sau la bărbaţii cu risc crescut de fractură, fiind util în prevenirea osteoporozei vertebrale, nonvertebrale, cât și la nivelul șoldului. Bifosfonaţii se adminstrează po dimineaţa cu 30 de minute înainte de masă sau de alte medicamente, cu $200 \mathrm{ml}$ apă și cu indicaţia de a menţine poziţia ortostatică minimum 30 de minute. Principalele reacţii adverse sunt cele gastrointestinale, cefalee, mialgii. De aceea, sunt de evitat în cazul refluxului esofagian, achalaziei imposibilităţii de păstrare a poziţiei 30 de minute; de asemenea, bifosfonaţii sunt contraindicaţi la gravide, în perioada de alăptare, în cazul afectării funcţiei renale (eRFG < 30-35 ml/min), în condiţii de hipocalcemie, când trebuie căutată și tratată cauza acesteia. În cazul administrării parenterale, la primele doze de bifosfonaţi pot apărea reacţii de tip pseudogripal, care pot să dispară la următoarele administrări, iar recent $s$-a descris și un risc de favorizare a apariţiei fibrilaţiei atriale. Pacienţii trataţi cu bifosfonaţi prezintă risc de osteonecroză maxilară (1/100.000/an), în special cei cu igienă defectuoasă a cavităţii bucale, cu afecţiuni stomatologice, cei supuși chimioterapiei sau corticoterapiei sau cei care prezintă metastaze osoase. Pacienţii raportează durere la nivelul maxilarului, creșterea mobilităţii dinţilor, tumefacţii; controlul stomatologic este obligatoriu la iniţierea terapiei cu bifosfonaţi, cât și periodică în cazul persoanelor la risc. O altă reacţie adversă, mai rar întâlnită, este osteonecroza la nivelul conductului auditiv extern, pacientul acuzând durere și infecţii cronice la acest nivel. Nu în ultimul rând, în cursul tratamentului cu bifosfonaţi, pacientul poate să acuze o durere în coapsă, șold sau inghinal brusc instalată, ceea ce ar putea sugera posibilitatea unei fracturi atipice de femur (subtrohanteriană sau diafizară), întâlnită într-un procent cuprins în intervalul 3,2-50/100.000/an. Uneori, aceasta poate să apară bilateral, de aceea este necesară investigarea imagistică (radiologic, RMN) bilaterală, urmată de oprirea terapiei cu bifosfonaţi și uneori rezolvarea chirurgicală a fracturilor prin osteosinteză. Dacă nu apar reacţii adverse, terapia cu bifosfonaţi este urmată de către pacient pe o durată de 5 ani (alendronat, risendronat, ibandronat) sau 3 ani (acid zolendronic); tratamentul trebuie urmat continuu, dar din păcate ade- 
renţa și persistenţa la tratament sunt foarte slabe (1). Studiile au arătat că după primul an renunţă $50 \%$ dintre bolnavi din diferite motive, tocmai din această cauză atât ghidul american, cât și cel european și cel australian subliniază importanţa unui tratament constant, continuu și de durată și admit și folosirea genericelor în tratament. Monitorizarea terapiei se face iniţial la 4 luni, la 12 luni și apoi anual de către medical de familie, cele mai importante fiind funcţia renală și nivelul calcemiei. Dacă după 5 ani de tratament pacientul nu a mai prezentat fracturi și scorul T > - 2,5 se instituie pauză și pacientul va fi reevaluat după o perioadă de 1,5-3 ani (FRAX, DMO). Efectele bifosfonaţilor se pot menţine și până la 6-10 ani de la oprirea terapiei. Dacă scorul $T \leq-2,5$ sau dacă pacientul prezintă fracturi în timpul tratamentului, se reevaluează bolnavul, aderenţa, o posibilă cauză de osteoporoză secundară și se continuă tratamentul.

Anticorpii monoclonali umani anti RANKL (denosumab) inactivează dezvoltarea și activitatea osteoclastelor, se folosesc ca tratament de linia a II-a la pacienţii care nu tolerează bifosfonaţii. Sunt indicaţi în osteoporoza postmenopauză și în osteoporoza la bărbaţii cu risc crescut de fractură, scăzând riscul de fracturi vertebrale și nevertebrale. Se administrează subcutan 60 mg la fiecare 6 luni. Poate da reacţii adverse la locul injectării (celulite, infecţii ale pielii) sau rareori osteonecroze. Este contraindicată administrarea în caz de hipocalcemie, la gravide și copii sub 18 ani, necesitând control calciului seric înainte de fiecare administrare. La 18 luni de la întreruperea tratamentului crește însă riscul de fracturi, fiind necesară administrarea de bifosfonaţi (8).

Terapia de substituţie hormonală este utilizată limitat, doar la femei tinere, sub 60 de ani, în primii 10 ani de menopauză, cu simptomatologie cauzată de această perioadă. Se administrează doar în cazurile selecţionate, pentru perioade scurte de câteva luni, pentru prevenirea osteoporozei și în scopul ameliorării simptomelor din cauza menopauzei. Modulatorii selectivi ai receptorilor estrogenici (raloxifen) sunt folosiţi de asemenea doar în situaţiile selecţionate exprimate mai sus, neindicându-se de rutină. Se administrează po 60 mg/zi, timp limitat, în acele situaţii în care se urmărește și efectul de ameliorare a simptomatologiei legate de menopauză. Ambele medicamente pot preveni osteoporoza vertebrală legată de menopauză, dar, din cauza reacţiilor adverse (complicaţii tromboembolice, sângerări genitale, creșterea riscului cancerului de endometru (2), creșterea riscului de accident vascular cerebral), sunt rareori indicate.

Calcitonina de somon sau calcitonina umană utilizată în trecut în tratarea osteoporozei, cu administrare im sau intranazală, astăzi nu mai este acceptată decât în SUA, utilizată în perioade foarte scurte (10 zile - maximum 3 luni) pentru efectul antalgic în cazul fracturilor. Ea a fost retrasă din Europa și Canada în anul 2013 de FDA și 2012 de către EMA, deoarece beneficiul pe termen lung în osteoporoză nu a fost dovedit, iar la reacţii adverse a fost identificat riscul crescut de cancer (2).

Ranelatul de stronţiu este un antiresorbtiv cu efect modest, dar cu risc crescut de evenimente cardiovasculare, tromboembolism, IMA, afectarea memoriei, cefalee, convulsii, alergii, fenomene de intoleranţă digestivă. În anul 2013, EMA a recomandat restricţie în utilizarea ranelatului de stronţiu la pacienţi cu afecţiuni cardiace, circulatorii.

PTH uman recombinat (teriparatide) este indicat în osteoporoza postmenopauză, osteoporoza la bărbaţi sau cea corticosteroid-indusă, având efecte demonstrate vertebrale și nonvertebrale, cu excepţia șoldului. Se administrează subcutan $20 \mu \mathrm{g} / z i$, pe o perioadă de maximum 24 de luni. Din cauza costului foarte ridicat, este destinat doar cazurilor foarte severe cu BMD $<-3,0$ care nu au răspuns la alte tratamente anterioare. Medicamentul este contraindicat în sarcină, lactaţie, boli metabolice osoase (Paget), neoplazii osoase, hipercalcemie.

Alţi agenţi terapeutici care ar putea reprezenta speranţe de viitor sunt inhibitorii de catepsină k (odanacatib, balicatib), care însă au produs îngroșarea pielii și s-a remarcat creșterea riscului de fibrilaţie atrială și accident vascular. Anticorpii antisclerostin ar putea, de asemenea, reprezenta o alternativă de tratament de viitor $(4,1)$.

Alegerea terapiei depinde de tipul de osteoporoză (pre sau postmenopauză, la bărbaţi, corticosteroid-indusă, alte etiologii), de comorbidităţi, de gradul de afectare renală. Ghidurile actuale recomandă ca primă linie de tratament, alături de măsurile nefarmacologice, vitamina D și calciu, administrarea bifosfonaţilor po (alendronat, risendronat), iar în caz de intoleranţă digestivă se pot utiliza bifosfonaţi parenteral sau anticorpii anti RANKL. Terapia hormonală sau modulatorii selectivi ai receptorilor estrogenici nu se utilizează de rutină, ci doar în cazuri selecţionate și pentru perioade scurte. În formele severe care nu răspund la tratament se poate re- 
curge la PTH recombinat, care însă este foarte scump (2). Efectul medicaţiei este mai evident pe osteoporoza vertebrală și nevertebrală și mai puţin evident pentru osteoporoza la nivelul șoldului (ibandronatul, calcitriolul, PTH recombinat, modulatorii de receptori estrogenici nu au efecte asupra șoldului dovedite în studii clinice). S-a încercat terapia combinată antiresorbtive cu stimulante ale osteoformării, dar rezultatele obţinute au fost sub așteptări, nedovedindu-și superioritatea; sunt necesare încă studii pentru găsirea celor mai bune soluţii. De asemenea, se desfășoară numeroase studii care să probeze eficienţa polifenolilor din ceaiul verde, a fitoestrogenilor, a acizilor grași omega 3, a izoflavonelor din soia, dar multe dintre ele sunt încă în faza de studii pe animale (2). Recent, utilizarea celulelor stem mezenchimale, precursoare de osteoblaste, pe animale de experienţă (șoareci) a permis obţinerea unor rezultate încurajatoare, îmbunătăţind osteoformarea la nivelul oaselor afectate.

Probabil că de viitor va fi și terapia genică, având în vedere că se consideră că $75 \%$ din determinismul osteoporozei este genetic. S-a ridicat însă problema existenţei a cel puţin două situsuri de acţiune, întrucât se consideră că o singură genă nu ar putea activa osteoblastul și osteoclastul deopotrivă. În fine, teorii mai noi cercetează descoperirea unor medicamente (senolytic drugs) care să omoare celulele îmbătrânite și care ar putea încetini evoluţia fiziologică a întregului proces de îmbătrânire, inclusiv ar putea întârzia apariţia osteoporozei.

Terapia osteoporozei cu siguranţă va suferi modificări în timp, însă ceea ce este important la nivelul asistenţei medicale primare este depistarea precoce a osteoporozei, evaluând periodic factorii de risc și instituirea tratamentului preventiv și curativ.

Conflict of interest: none declared Financial support: none declared

\section{BIBLIOGRAFIE}

1. Camacho P., Petak S. et al. AACE/ACE Guidelines. Endocrine Practice. 2016 sept; 22.

2. Souza M.P.G.D. Osteoporosis diagnosis and treatment. Rev Bras Ortop. 2010 May-Jun; 45(3).

3. Kanis J., McCloskey E, Johansson H., A.O., Ström O., Borgström F. Development and use of FRAX in osteoporosis. Osteoporosis Int. 2010 Jun, 21; Suppl2.

4. Compston J., Cooper A., Cooper C. et al. UK clinical guideline for the prevention and treatment of osteoporosis. Arch Osteoporos. 2017 Apr 19; 12(1)(43).
5. Pai M. Osteoporosis Prevention and Management. J Obstet Gynaecol India. 2017 Aug; 67(4): 237-242.

6. Tella S., Gallagher J. Prevention and treatment of postmenopausal osteoporosis. J Steroid Biochem Mol Biol. 2014 Jul; 142: 155-70.

7. Amir Q.F.M., McLean R. et al. Treatment of Low Bone Density or Osteoporosis to Prevent Fractures in Men and Women: A Clinical Practice Guideline Update From the American College of Physicians. Annals of Internal Medicine. 2017 june.

8. Faienza M., Chiarito M. et al. Monoclonal antibodies for treating osteoporosis. Expert Opin Biol Ther. 2017 Nov 7; 1-9.
9. Hsiao F., Hsu W. Comparative risks for cancer associated with use of calcitonin, bisphosphonates or selective estrogen receptor modulators among osteoporosis patients: a population-based cohort study. Jpn J Clin Oncol. 2017 Oct; 1(47).

10. Pundole $X$. et al. Anti-sclerostin antibodies for the treatment of osteoporosis. Cochrane Library. 2017 apr.

11. Ozra T.M., P.S., P.K., B.L. New horizons in treatment of osteoporosis. Daru J.of Pharm. Sciences. 2017 25; 2.

12. NOGG 2017: Clinical guideline for the prevention and treatment of osteoporosis. 